\title{
Role of Nicotinamide in Streptozotocin Induced Diabetes in Animal Models
}

\author{
Lalit Kishore, Anu Kajal and Navpreet Kaur* \\ MM University, India
}

Submission: April 01, 2017; Published: May 24, 2017

*Corresponding author: Navpreet Kaur, MM College of Pharmacy, MM University, Mullana-Ambala, Haryana 133207, India, Tel: +91-9729934385/+91-8295954281; Email: nav.dhillon1617@gmail.com

\begin{abstract}
Diabetes mellitus (DM) is a metabolic disease with abnormal glucose homeostasis, due to defects in secretion or action of insulin. It is a potentially morbid condition with high prevalence worldwide and has become a major medical concern. Animal models play an important role in understanding such type of diseases. Diabetes in experimental animal develops either spontaneously or by using chemical, surgical, genetic or other techniques, and depicts many clinical features or related phenotypes of the disease. Streptozotocin (STZ) is a widely used chemical for the induction of experimental diabetes in animals. In this review, we have provided the evidences related to the fact that Nicotinamide play a protective role against destruction of pancreatic $\beta$ - cells in STZ induced diabetes model in experimental animals..
\end{abstract}

Keywords: Diabetes mellitus; STZ; Nicotinamide

\section{Introduction}

Diabetes mellitus (DM) is mainly characterized by hyperglycemia [1] with an imbalance of carbohydrate, protein and fat metabolism due to reduced production of insulin from pancreas (defects in insulin secretion), or when insulin cannot be used efficiently by the body (defect in insulin action), or both $[1,2]$. Two major forms of diabetes are Type I DM (TIDM) and Type II DM (TIIDM). TIDM is also termed as insulin dependent DM (IDDM) and TIIDM as non insulin dependent DM (NIDDM). TIDM is immune mediated and is characterized by destruction of pancreatic $\beta$-cells and requires daily administration of exogenous insulin [3]. TIIDM is the most prevalent form of diabetes, mainly characterized by partial destruction of pancreatic $\beta$-cells, which results in relative insulin deficiency/ resistance $[2,4]$. About $5-10 \%$ diabetic patients have TIDM as it affects 3 in 1000 children whereas TIIDM is considered to be the most prevailing form of diabetes, which accounts for about $90 \%$ of diabetic cases [5].

Animal models have been used widely to obtain knowledge of various pathological conditions related to diseases such as diabetes. STZ induced diabetes is considered to be the most reliable method. STZ induced structural, functional and biochemical alterations observed are similar to those which appear with diabetes in human [6]. Therefore STZ-induced diabetes represents a clinically relevant model to study the pathogenesis of diabetes and associated complication.

\section{Streptozotocin (STZ)}

STZ (2-deoxy-D-glucose derivative of N-methyl-Nnitrosylurea) is a glucosamine nitrosourea, hydrophilic compound which was first isolated from a soil microorganism Streptomyces acromogenes and showed broad spectrum antibiotic activity $[7,8]$.

The diabetogenic action of STZ is related to its selective destruction of pancreatic $\beta$-cells, which are the only source of insulin in body. As STZ is glucose derivative, the blood glucose moieties enables STZ to be selectively transported to pancreatic $\beta$-cells via the low-affinity GLUT2 glucose transporter in the plasma membrane $[9,10]$.

Exposure of STZ to pancreatic $\beta$-cells results in damage via different pathways:

a. STZ destructs $\beta$-cells by damaging the major macromolecule i.e. DNA by alkylating. Alkylation of DNA results in fragmentation of DNA in $\beta$-cells $[10,11]$. DNA injury by STZ leads to overstimulation of PARP-1 [(poly(ADPribose) polymerase-1] in the insulin-secreting cells and is harmful to the cell as a result of a substantial depletion of the intracellular PARP-1 substrate, NAD+. NAD+ is an important molecule implicated in energy metabolism at the cellular level $[12,13]$. 
b. STZ also decreases the activity of islet mitochondrial aconitase, reduces oxygen consumption by mitochondria and decreases the mitochondrial membrane potential [14].

c. Generation of nitric oxide may play a role in the cytotoxic action of STZ on insulin-secreting cells. This assumption is supported by results demonstrating that scavengers of nitric oxide (NO) attenuate early DNA-strand breaks induced by STZ [15].

d. STZ generates low amounts of ROS in pancreatic $\beta$-cells. These effects may partially contribute to $\beta$-cells damage induced by STZ because of a weak antioxidant defense in these cells $[16,17]$.

e. It has also been revealed that c-Jun N-terminal kinase (JNK) is also involved in the cytotoxicity of STZ. Increased activity of this enzyme is observed in the case of cellular stress leading to cell death. Studies on insulin-secreting cells exposed to STZ demonstrated increased activity of JNK, whereas inhibitors of this enzyme attenuated the cytotoxic action of STZ. Activation of JNK by STZ is supposed to be preceded by increased activity of PARP-1 since PARP-1 inhibitors are able to decrease the activity of both PARP-1 and JNK [18].

\section{Nicotinamide (NIC)}

NIC (pyridine-3-carboxamide) also known as niacinamide, is an active and water soluble form of vitamin B3 (niacin). Niacine converted into NIC in the body and is a food additive. NIC is essential to the coenzymes NADH and NADPH and consequently for numerous enzymatic reactions in the body including formation of ATP. NIC has neuro-protective and antioxidant functions and is given to animals to partially protect pancreatic $\beta$-cells against STZ $[19,20]$.

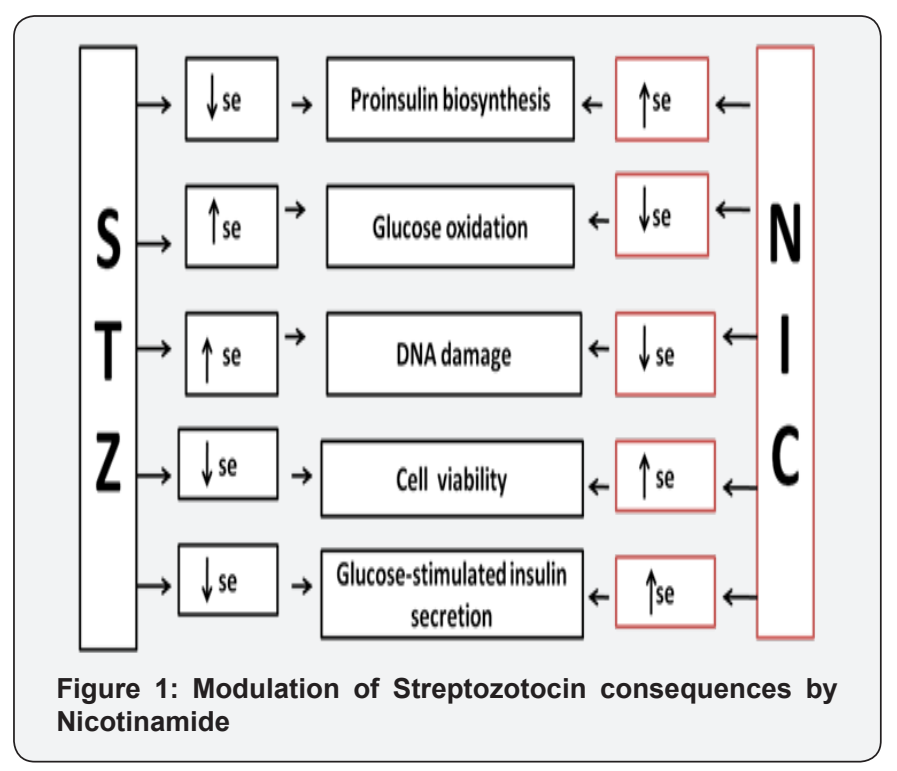

Numerous in vitro experimental studies conducted on isolated rat pancreatic islets have revealed that effects of STZ like reduction of pro-insulin biosynthesis, inhibition of glucosestimulated insulin secretion etc. were modulated by NIC [21-24] (Figure 1).

NIC shows its partial protection against STZ induced destruction of $\beta$-cells by two major mechanisms i.e. either by inhibiting PARP-1 $[13,25]$ or by increasing the concentration of NAD+ (by reducing utilization of NAD+ or by increasing its biosynthesis) [26] (Figure 2).

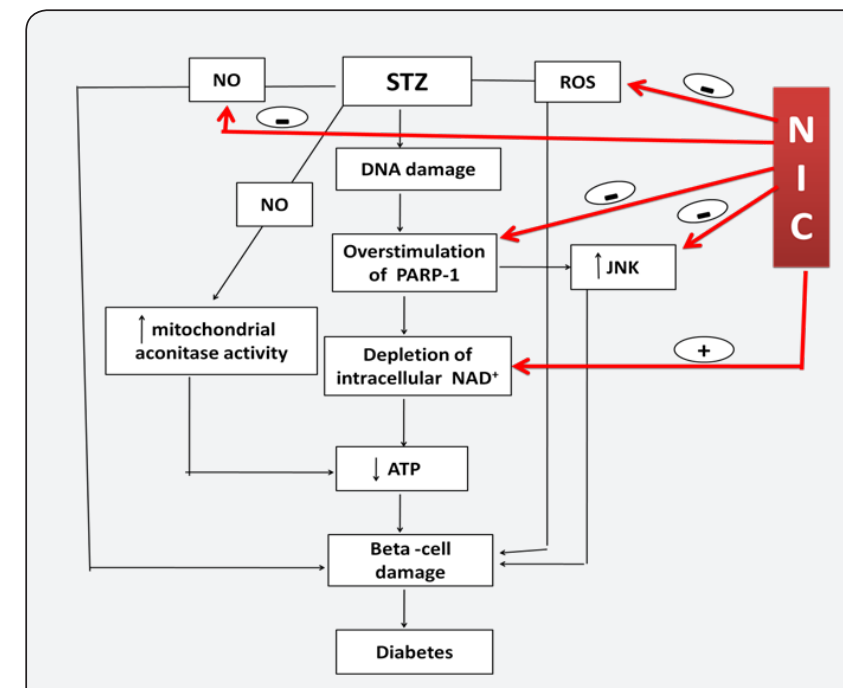

Figure 2: Role of Nicotinamide in partial protection of $\beta$ - cells in Streptozotocin induced diabetes model

\section{Type of Diabetes Induced by STZ}

The single intravenous dose between 40 and $60 \mathrm{mg} / \mathrm{kg}$ body weight in adult rats can induce TIDM [27], but higher doses are also used. STZ is also efficacious after intraperitoneal administration of a similar or higher dose [28]. STZ may also be given in multiple low doses. Such treatment is used predominantly in the mouse and the induction of IDDM is mediated by the activation of immune mechanisms. The nonspecific activation of the immune system via complete Freund's adjuvant prior to STZ injections allows to reduce its diabetogenic dose even in the rat $[29,30]$.

NIDDM can easily be induced in rats by intravenous or intraperitoneal treatment with $100 \mathrm{mg} / \mathrm{kg}$ body weight STZ on the day of birth. This method of NIDDM induction was described for the first time by Portha et al. [31]. At 8-10 weeks of age and thereafter, rats neonatally treated with STZ manifest mild basal hyperglycemia, an impaired response to the glucose tolerance test and a loss of $\beta$-cells sensitivity to glucose [32]. But in adult rats, if NIC is administered at a dose range of $100-500 \mathrm{mg} / \mathrm{kg}$ prior to the administration of STZ it leads to cytoprotective effect. It should be emphasized that the effects induced in rats by STZ and NIC vary depending on the doses of these two compounds, the age of the animals and the time of NIC administration in relation to the administration of STZ $[19,20]$. Factors, such as the administration route of STZ and the nutritional state of rats may also have some influence. In the case of relatively low doses of NIC given to rats, its protective action is negligible. Conversely, 
high doses of NIC may provide total protection [8,27]. The age of rats is also of major importance since $\beta$-cells of younger animals are less sensitive to STZ and are better protected by NIC. It is also known that the protective action of NIC on $\beta$-cells decreases with the time elapsed after administration of STZ to rats. This decrease is supposed to result from ATP depletion since the uptake of NIC by $\beta$-cells is ATP-dependent. In the majority of experiments, NIC is given to rats $15 \mathrm{~min}$ before STZ [32].

\section{Conclusion}

STZ-induced diabetes is a clinically important animal model and most extensively used to mimic human diabetic condition. STZ can produce both types of DM i.e., TIDM and TIIDM depending on the dose and route of administration but couldn't be affective every time. But the role of NIC is worth considering which can modulate the occurrence of type of DM via its cytoprotective action against the toxic effect of STZ at a particular dose.

\section{References}

1. International Diabetes Federation (2009) Diabetes Atlas. (4 $4^{\text {th }}$ edn), International Diabetes Federation, Brusesls, Belgium.

2. Alberti KG, Zimmet PZ (1998) Definition, diagnosis and classification of diabetes mellitus and its complications. Part 1: diagnosis and classification of diabetes mellitus. Provisional report of a WHO Consultation. Diabet Med 15(7): 539-553.

3. Aalto A (1999) Diabetes Cognition and Social Support in the Management of Diabetes. A cross sectional studies on social psychological determinants of health-related quality of life and selfcare among adults with type 1 diabetes. Faculty of Social Sciences, Department of Social Psychology, University of Helsinki, Finland.

4. Naemiratch B, Manderson L (2007) Lay Explanations of Type 2 Diabetes in Bangkok, Thailand. Anthropol Med 14(1): 83-94.

5. Deshpande AD, Harris-HM, Schootman M (2008) Epidemiology of Diabetes and Diabetes-Related Complications. Phys Ther 88(11): 1254-1264.

6. Eleazu CO, Eleazu KC, Chukwuma S, Essien UN (2013) Review of the mechanism of cell death resulting from streptozotocin challenge in experimental animals, its practical use and potential risk to humans. J Diabetes Metab disord 12(1): 60-67.

7. Goud BJ, Dwarakanath V, Chikka swamy BK (2015) Streptozotocin-A diabetogenic agent in animal models. Int J Pharm Pharm Res 3(2015): 253-269.

8. Reusser F (1971) Mode of action of streptozotocin. J Bacteriol 105(2): 580-588.

9. Schnedl WJ, Ferber S, Johnson JH, Newgard CB (1994) STZ transport and cytotoxicity. Specific enhancement in GLUT2-expressing cells. Diabetes 43(11):1326-1333.

10. Elsner M, Guldbakke B, Tiedge M, Munday R, Lenzen S (2000) Relative importance of transport and alkylation for pancreatic beta-cell toxicity of streptozotocin. Diabetologia 43(12):1528-1533.

11. Takasu N, Komiya I, Asawa T, Nagasawa Y, Yamada T (1991) Streptozocin and alloxan-induced $\mathrm{H} 2 \mathrm{O} 2$ generation and DNA fragmentation in pancreatic islets. $\mathrm{H} 2 \mathrm{O} 2$ as mediator for DNA fragmentation. Diabetes 40(9): 1141-1145.

12. Satoh MS, Lindahl T (1992) Role of poly(ADP-ribose) formation in DNA repair. Nature 356(6367): 356-358.
13. Cepeda V, Fuertes MA, Castilla J, Alonso C, Quevedo C, et al. (2006) Poly(ADP-ribose) polymerase-1 (PARP-1) inhibitors in cancer chemotherapy. Rec Pat Anticanc Drug Discov 1(1): 39-53.

14. Jeng JY, Yeh TS, Chiu YH, Lee YC, Cheng HH, et al. (2009) Linoleic acid promotes mitochondrial biogenesis and maintains mitochondrial structure for prevention of streptozotocin damage in RIN-m5F cells. Biosci Biotechnol Biochem 73(6): 1262-1267.

15. Turk J, Corbett JA, Ramanadham S, Bohrer A, McDaniel ML (1993) Biochemical evidence for nitric oxide formation from streptozotocin in isolated pancreatic islets. Biochem Biophys Res Commun 197(3): $1458-1464$

16. Nukatsuka M, Sakurai H, Yoshimura Y, Nishida M, Kawada J (1988) Enhancement by streptozotocin of $\mathrm{O}^{2-}$ radical generation by the xanthine oxidase system of pancreatic beta-cells. FEBS Lett 239(2): 295-298.

17. Lenzen S (2008) Oxidative stress: the vulnerable beta-cell. Biochem Soc Trans 36(pt 3): 343-347.

18. Cheon H, Cho JM, Kim S, Baek SH, Lee MK, et al. (2010) Role of JNK activation in pancreatic beta-cell death by streptozotocin. Mol Cell Endocrinol 321(12): 131-137.

19. Zhou SS, Li D, Sun WP, Guo M, Lun YZ, et al. (2009) Nicotinamide overload may play a role in the development of type 2 diabetes. World J Gastroenterol 15(45): 5674-5684.

20. Williams A, Ramsden D (2005) Nicotinamide: a double edged sword. Parkinsonism Relat Disord 11(7): 413-420.

21. Uchigata Y, Yamamoto H, Kawamura A, Okamoto H (1982) Protection by superoxide dismutase, catalase, and poly(ADP-ribose) synthetase inhibitors against alloxan- and streptozotocin-induced islet DNA strand breaks and against the inhibition of proinsulin synthesis. J Biol Chem 257(11): 6084-6088.

22. Akpan JO, Wright PH, Dulin WE (1987) A comparison of the effects of streptozotocin, $\mathrm{N}$-methylnitrosourea and alloxan on isolated islets of Langerhans. Diabete Metab 13(2): 122-128.

23. Masiello P, Novelli M, Fierabracci V, Bergamini E (1990) Protection by 3-aminobenzamide and nicotinamide against streptozotocin-induced beta-cell toxicity in vivo and in vitro. Res Commun Chem Pathol Pharmacol 69(1): 17-32.

24. Heller B, Bürkle A, Radons J, Fengler E, Jalowy A, et al. (1994) Analysis of oxygen radical toxicity in pancreatic islets at the single cell level. Biol Chem Hoppe Seyler 375(9): 597-602.

25. Pandya KG, Patel MR, Lau-CCA (2010) Comparative study of the binding characteristics to and inhibitory potencies towards PARP and in vivo antidiabetogenic potencies of taurine, 3 -aminobenzamide and nicotinamide. J Biomed Sci 17(Suppl 1): S16.

26. Jackson TM, Rawling JM, Roebuck BD, Kirkland JB (1995) Large supplements of nicotinic acid and nicotinamide increase tissue $\mathrm{NAD}^{+}$ and poly(ADP-ribose) levels but do not affect diethylnitrosamineinduced altered hepatic foci in Fischer-344 rats. J Nutr 125(6): 14551461.

27. Ganda OP, Rossi AA, Like AA (1976) Studies on streptozotocin diabetes. Diabetes 25(7): 595-603.

28. Katsumata K, Katsumata K, Katsumata Y (1992) Protective effect of diltiazem hydrochloride on the occurrence of alloxan- or streptozotocininduced diabetes in rats. Horm Metab Res 24(11): 508-510.

29. Ziegler M, Ziegler B, Hehmke B (1984) Severe hyperglycaemia caused autoimmunization to beta cells in rats. Diabetologia 27: 163-165.

30. Wright JR, Lacy PE (1988) Synergistic effects of adjuvants, endotoxin, and fasting on induction of diabetes with multiple low doses of streptozotocin in rats. Diabetes 37(1): 112-118. 
31. Portha B, Levacher C, Picon L, Rosselin G (1974) Diabetogenic effect of streptozotocin in the rat during the perinatal period. Diabetes 23(11): 889-895.

This work is licensed under Creative Commons Attribution 4.0 Licens

DOI: 10.19080/JETR.2017.02.555577
32. Szkudelski T (2012) Streptozotocin- Nicotinamide induced diabetes in the rat. Charecteristics of the experimental model. Exp Biol Med (Maywood) 237(5): 481-490.

\section{Your next submission with Juniper Publishers} will reach you the below assets

- Quality Editorial service

- Swift Peer Review

- Reprints availability

- E-prints Service

- Manuscript Podcast for convenient understanding

- Global attainment for your research

- Manuscript accessibility in different formats

( Pdf, E-pub, Full Text, Audio)

- Unceasing customer service

Track the below URL for one-step submission https://juniperpublishers.com/online-submission.php 